\title{
1 Can we predict antibody responses in SARS-CoV-2? A cohort
}

\section{2 analysis.}

3 Running title: Predict SARS-Cov-2 antibody response

\section{Authors:}

5 Mary Gaeddert (1), Philip Kitchen (1), Tobias Broger (1), Stefan Weber (1), Ralf

6 Bartenschlager (2), Anna Plaszczyca (2), Hans-Georg Kräusslich (3), Barbara Müller

7 (3), Margarida Souto-Carneiro (4), Maike Janssen (4), Carsten Müller-Tidow (4), Uta

8 Merle (5), Yannis Herrmann (1), Lukas Raedeker (1), Jakob Sebastian (1), Niall

9 Brindl (1), Tim Starck (6), Claudia M. Denkinger (1)

\section{Author affiliations:}

1. Division of Tropical Medicine, Center of Infectious Diseases, Heidelberg University Hospital, Germany

2. Department of Infectious Diseases, Molecular Virology, Heidelberg University Hospital, Heidelberg, Germany

3. Virology, Center of Infectious Diseases, Heidelberg University Hospital, Heidelberg, Germany

4. Department of Internal Medicine V, Heidelberg University Hospital, Heidelberg, Germany.

5. Department of Gastroenterology, Heidelberg University Hospital, Germany 
medRxiv preprint doi: https://doi.org/10.1101/2021.03.15.21253267; this version posted March 17, 2021. The copyright holder for this preprint (which was not certified by peer review) is the author/funder, who has granted medRxiv a license to display the preprint in perpetuity.

It is made available under a CC-BY-NC-ND 4.0 International license .

\section{Corresponding author:}

24 Claudia M. Denkinger, Claudia.Denkinger@uni-heidelberg.de, Phone: 00496221 56-

22999, Fax: 00496221 56-5204

Abstract word count: $200 / 200$

Text word count: $2,799 / 3,500$

\section{Abstract}

30 Background: After infection with severe acute respiratory syndrome coronavirus

31 (SARS-CoV-2), Immunoglobulin G ( $\lg G)$ antibodies and virus-specific neutralizing antibodies (nAbs) develop. This study describes antibody responses in a cohort of recovered COVID-19 patients to identify predictors.

Methods: We recruited patients with confirmed SARS-CoV-2 infection from Heidelberg, Germany. Blood samples were collected three weeks after COVID-19 symptoms ended. Participants with high antibody titers were invited for follow-up visits. IgG titers were measured by the Euroimmun Assay, and nAbs titers in a SARS-CoV-2 infection-based assay.

Results: 281 participants were enrolled between April and August 2020 with IgG 42 testing, $145(51.6 \%)$ had nAbs, and 35 (12.5\%) had follow-up. The median IgG 43 optical density (OD) ratio was 3.1 (Interquartile range (IQR) 1.6-5.1), and 24.1\% $44(35 / 145)$ had a nAb titer $>1: 80$. Higher IgG titers were associated with increased age and more severe disease, and higher nAbs were associated with male gender and 
medRxiv preprint doi: https://doi.org/10.1101/2021.03.15.21253267; this version posted March 17, 2021. The copyright holder for this preprint (which was not certified by peer review) is the author/funder, who has granted medRxiv a license to display the preprint in perpetuity. It is made available under a CC-BY-NC-ND 4.0 International license.

46 CT-value of $25-30$ on RT-PCR at diagnosis. The median IgG OD ratio on follow-up

47 was 3.7 (IQR 2.9-5.9), a median increase of 0.5 (IQR -0.3-1.7). Six participants with

48 follow-up nAbs all had titers $\leq 1: 80$.

49

50 Conclusions: While age and disease severity were correlated with $\lg$ G responses, 51 predictive factors for nAbs in convalescent patients remain unclear.

52

53 Keywords: antibody, IgG, neutralizing antibodies, seroconversion, SARS-CoV-2, 54 COVID-19

55

56 
medRxiv preprint doi: https://doi.org/10.1101/2021.03.15.21253267; this version posted March 17, 2021. The copyright holder for this preprint (which was not certified by peer review) is the author/funder, who has granted medRxiv a license to display the preprint in perpetuity.

It is made available under a CC-BY-NC-ND 4.0 International license .

\section{Introduction}

58 An understanding of the robustness of the antibody response against severe acute respiratory syndrome coronavirus 2 (SARS-CoV-2) and its longevity is critical to determine the necessary levels and duration of antibody titers that confer protection against re-infection.

62

After infection with the severe acute respiratory syndrome coronavirus 2 (SARS-CoV-

2), about two thirds of hospitalized patients show IgG seroconversion within the first two weeks of infection [1] while later it will be up to $90 \%$ [2]. In contrast for mild cases, seroconversion might only be observed in 48\% [2]. Previous studies in

67 hospitalized patients with Coronavirus disease 2019 (COVID-19) indicate some correlation between disease severity and strength of the antibody response [3-6].

69 Also, studies have reported varying results regarding the change of IgG antibodies over time, with some evidence that this time course may also be related to disease severity [6-8].

73 Virus-specific neutralizing antibodies (nAbs) have the ability to inhibit virus replication

74 in an ongoing infection and are likely to play a role in preventing re-infection. It has been shown that SARS-CoV-2 infection can result in the production of antibodies with neutralizing properties in vitro and protective effects in animal models [9].

77 However, the precise correlation between lgG levels and nAb response [10], as well 78 as the predictors of $\mathrm{nAbs}$ in an effective and durable immune response against 79 SARS-CoV-2 [9, 11] have not been clarified. Similar to IgG levels, nAbs may 
medRxiv preprint doi: https://doi.org/10.1101/2021.03.15.21253267; this version posted March 17, 2021. The copyright holder for this preprint (which was not certified by peer review) is the author/funder, who has granted medRxiv a license to display the preprint in perpetuity.

It is made available under a CC-BY-NC-ND 4.0 International license .

80 decrease several months after infection, but tend to remain higher following

81 symptomatic infection compared with asymptomatic [8].

82

83 Understanding the levels of $\lg G$ and $n A b s$ that are relevant for protection is also

84 important for the use of convalescent plasma in the treatment of SARS-CoV-2.

85 Convalescent plasma has already been authorized by the FDA under Emergency

86 Use Authorization [12, 13], however the impact on patient outcomes has been

87 variable $[14,15]$. There is therefore also an urgent need to identify factors that predict

88 which convalescent patients will have robust immune responses to SARS-CoV-2

89 infection and be suitable to serve as plasma donors.

90

91 The aim of this study is to describe the antibody response in a cohort of recovered

92 COVID-19 patients and identify predictors of total IgG and neutralizing antibody

93 responses. The results will be useful in identifying the most suitable plasma donors

94 and may further contribute to understanding the risk for future re-infection.

95

96 Methods

97 Study design and participants

98 Convalescent COVID-19 patients from the Rhein-Neckar region surrounding

99 Heidelberg, Germany, were recruited for this study. Participants were identified by

100 the local Public Health Authority as meeting the current guidelines for COVID testing

101 (exposure to a SARS CoV-2 positive case, suggestive symptoms, or travel to a risk 
medRxiv preprint doi: https://doi.org/10.1101/2021.03.15.21253267; this version posted March 17, 2021. The copyright holder for this preprint (which was not certified by peer review) is the author/funder, who has granted medRxiv a license to display the preprint in perpetuity.

It is made available under a CC-BY-NC-ND 4.0 International license .

102 area) and were tested in a certified test center in the Heidelberg area. Those who

103 tested positive for SARS-CoV-2 infection were contacted approximately two to three

104 weeks after the positive test and asked to participate in the study. A survey

105 conducted online or by telephone collected retrospective data on demographic and

106 clinical information, including symptoms, hospitalization, and measures of COVID-19

107 disease severity. After survey completion, participants were screened for potential

108 plasma donation. The inclusion criteria for plasma donation were age less than 65

109 years and no comorbidities. Participants from outside the Rhein Neckar region were

110 also recruited through a public advertisement of the COVID-19 plasma donor

111 program. These participants followed the procedures below but did not complete the

112 survey and are missing the demographic and clinical information.

114 The first study visit was conducted at the Heidelberg University Hospital at least three

115 weeks after symptoms ended. During this visit, a nasopharyngeal swab and blood

116 samples were collected for testing as described below. Convalescent patients with

117 high IgG levels (optical density (OD) ratio $>2.5$ ) and a nAbs titer (> 1:80) were invited

118 to participate as plasma donors. Serologic testing was performed again at the time of 119 plasma donation.

120

121 All procedures were performed in accordance with the ethical standards of the

122 institutional research committee of Heidelberg University (study approval number

123 S686/2018). Written informed consent was obtained from each participant. 
medRxiv preprint doi: https://doi.org/10.1101/2021.03.15.21253267; this version posted March 17, 2021. The copyright holder for this preprint (which was not certified by peer review) is the author/funder, who has granted medRxiv a license to display the preprint in perpetuity.

It is made available under a CC-BY-NC-ND 4.0 International license .

\section{Molecular Assays}

126 Nasopharyngeal swabs (eSwabs, Copan) were analyzed with Allplex 2019-nCoV

127 Assay (Seegene Inc, Seoul, South Korea) and Tib-Molbiol 2019-nCoV LightMix (TIB

128 Molbiol, Berlin, Germany) for viral RNA using reverse-transcriptase polymerase chain

129 reaction (RT-PCR) designed to detect RdRP and N genes specific for SARS-CoV-2

130 and the E gene for all of Sarbecovirus including SARS-CoV-2. Cycle threshold-

131 values (CT-values) under 38 were considered positive.

\section{Serological Assay}

134 Enzyme linked immunosorbent assay (ELISA) measurements for determination of $135 \lg$ G reactivity against the $\mathrm{S} 1$ domain of the viral spike (S) protein were carried out 136 using the Euroimmun Anti-SARS-CoV-2-ELISA (IgG) (El 2606-9601 G;

137 EUROIMMUN Medizinische Labordiagnostika AG, Lübeck, Germany) test kit 138 according to the manufacturer's protocol. Samples were processed on an

139 Euroimmun Analyzer I instrument according to the manufacturer's instructions.

140 Immunoreactivity was determined by measuring the optical density at $450 \mathrm{~nm}$

141 (OD450) and divided by the OD450 of a calibrator comprised in the kit to minimize

142 inter-assay variation. The interpretation of the semi-quantitative ratiometric values

143 obtained followed the manufacturer's test instructions: ratios $<0.8$ were classified as

144 negative, $0.8-1.1$ as borderline, and $\geq 1.1$ or higher as positive. Sera with an OD ratio

$145>2.5$ were tested for the presence of neutralizing antibodies. A subset of samples

146 was also tested with an ELISA assay targeting viral nucleocapsid antigen using the

147 EDI $^{\mathrm{TM}}$ Novel Coronavirus COVID-19 IgG ELISA Kit (Epitope Diaganostics Inc, San 
medRxiv preprint doi: https://doi.org/10.1101/2021.03.15.21253267; this version posted March 17, 2021. The copyright holder for this preprint (which was not certified by peer review) is the author/funder, who has granted medRxiv a license to display the preprint in perpetuity.

It is made available under a CC-BY-NC-ND 4.0 International license .

148 Diego CA, USA), according to the manufacturer's instructions. Samples were

149 analyzed in the SpectraMax $\mathrm{M}^{\mathrm{e}}$ multi-detection microplate reader (Molecular

150 Devices, USA) at 450nm. Samples with an O.D. at $450 \mathrm{~nm} \geq 0.22$ were considered

151 positive. To minimize inter-assay variation the O.D. values were divided by the kit's

152 internal calibration control. The interpretation of the semi-quantitative ratiometric

153 values was carried out similarly as for the S1 domain of the viral spike protein.

154

155

Neutralization assay

156 VeroE6 cells were seeded into 96-well plates one day before the assay. Serial

157 dilutions of sera starting from a 1:10 dilution were prepared in OptiMEM

158 (ThermoFisher Scientific, Waltham, MA, USA) in a final volume of $75 \mu$ and 159 incubated with 24,000 PFU of SARS-CoV-2 (BavPat1/2020 strain, European Virus

160 Archive) per well for 1 hour at $37^{\circ} \mathrm{C}$ in a final volume of $150 \mu$ l. One third of each

161 serum-virus mixture $(50 \mu \mathrm{l})$ was then used for infection (final $\mathrm{MOI} \sim 0.25)$. Infections

162 were performed in duplicates. At 20 hours post-infection, cells were fixed with $5 \%$

163 formaldehyde and immune-stained using a primary mouse antiserum binding to

164 double-stranded RNA, a viral replication intermediate (J2 mouse antibody; Scicons,

165 Szirák, Hungary) and a secondary anti-mouse horseradish peroxidase-coupled

166 antibody (Merck, Darmstadt, Germany). The signal was developed using the KPL

167 SureBlueTM TMB peroxidase substrate (Seracare, Milford, MA, USA) and measured

168 in a plate reader at a wavelength of $450 \mathrm{~nm}$. Data were normalized to no-serum

169 control (100\%) and mock-infected control (0\%). The neutralization (NT) titer was 
medRxiv preprint doi: https://doi.org/10.1101/2021.03.15.21253267; this version posted March 17, 2021. The copyright holder for this preprint (which was not certified by peer review) is the author/funder, who has granted medRxiv a license to display the preprint in perpetuity.

It is made available under a CC-BY-NC-ND 4.0 International license .

170 defined as the highest serum dilution resulting in more than $50 \%$ reduction of the

171 normalized signal.

172

173 Statistical Analysis

174 We assessed factors associated with antibody response by analyzing demographic

175 and clinical characteristics of participants with different levels of IgG and nAbs. Linear

176 regression was performed to determine the association of demographic and clinical

177 characteristics with IgG antibody titers as a continuous outcome. Logistic regression

178 was performed to study the association of the same covariates with nAbs as a

179 categorial outcome. For both regression analyses, factors with a $p$-value $<0.1$ in the

180 univariate analysis were included in the multivariable model, and retained in the

181 model if the $p$-value was $<0.05$ using manual backward elimination. IgG titers from

182 convalescent and follow-up samples were compared using the Wilcoxon matched-

183 pairs signed-ranks test. Analysis was performed using Stata version 15.1 (StataCorp

184 LLC. College Station, TX).

185

186

Definitions

187 The first swab collected by the Public Health Authority for initial diagnosis of SARS-

188 CoV-2 infection is referred to as the 'diagnostic swab', and the second swab

189 collected at the screening visit for plasma donation is referred to as the "convalescent

190 swab'. An IgG OD ratio $<1.1$ was defined as negative, 1.1 to 2.5 as weak positive,

191 and $>2.5$ as high positive. NAbs were categorized into high and low, with titers $\leq 1: 80$ 
medRxiv preprint doi: https://doi.org/10.1101/2021.03.15.21253267; this version posted March 17, 2021. The copyright holder for this preprint (which was not certified by peer review) is the author/funder, who has granted medRxiv a license to display the preprint in perpetuity.

It is made available under a CC-BY-NC-ND 4.0 International license .

192 defined as low and $>1: 80$ as high by expert consensus after review of data from an

193 inpatient cohort.

194

195 An illness severity score was created using a combination of self-reported activity

196 restriction, the presence of COVID-19 symptoms indicative of severe disease (cough,

197 fever, or dyspnea), and hospitalization. The categories were defined as mild illness

198 (normal activity, none of the three symptoms, and not hospitalized), moderate illness

199 (restricted activity, symptomatic, and not hospitalized), and severe illness (severely

200 restricted activity, symptomatic, and hospitalized).

201

202 Results

203 A total of 281 participants were enrolled between April and August 2020. Survey 204 responses were available for 200 (71.2\%) participants. The population was 55\% 205 (107/194) male with a median age of 39 ([Interquartile range] IQR 29-50) (Table 1).

206 Only 3/171 (1.8\%) participants were hospitalized, with one in intensive care. The 207 median CT-value at the time of diagnosis was available for $165 / 281$ and was 25 (IQR

20820 to 28). IgG testing was performed for all 281 participants and of these, ODs were $209>2.5$ in 145 (51.6\%). Thirty-five participants (12.5\%) had serology repeated at the 210 time of plasma donation.

211

212 Convalescent samples were collected from all participants a median of 34 days (IQR

213 28-43) after the diagnostic swab and 29 days (IQR 22 to 37) after the end of 
medRxiv preprint doi: https://doi.org/10.1101/2021.03.15.21253267; this version posted March 17, 2021. The copyright holder for this preprint (which was not certified by peer review) is the author/funder, who has granted medRxiv a license to display the preprint in perpetuity.

It is made available under a CC-BY-NC-ND 4.0 International license .

214 symptoms. The median IgG OD ratio at the convalescent visit was 3.1 (IQR 1.6 to

2155.1 , with $58.7 \%$ (165/281) of participants categorized as having a highly positive 216 antibody response, $26.0 \%(73 / 281)$ with a positive response, and $15.3 \% 43 / 281$

217 (15.3\%) with a negative or borderline IgG antibody response. Only $24.1 \%$ of the 218 tested participants (35/145) displayed a nAb titer $>1: 80$. All three hospitalized 219 participants displayed nAb titers of 1:160. The convalescent swab was positive by 220 RT-PCR in 9.1\% (25/274) of participants and the median CT value was 37 (IQR 35 to 221 38). Of those who had a positive convalescent swab, 25\% (5/20) had nAbs >1:80.

223 The IgG convalescent titer was highest in adults 18 to 29 years old, decreasing in 30 224 to 44-year-olds, and increasing again in adults 45 to 60 years of age (Table 2 and 225 Figure 1). The nAbs titers, in contrast, did not show a statistically significant change 226 by age (Table 3 and Supplemental Figure 1). There was a correlation between

227 increasing $\lg \mathrm{G}$ titer and nAbs titer although Kappa was low (OR=1.6 ([95\% 228 Confidence Interval] 95\%Cl 1.3-1.9), $\mathrm{p}<0.001$, Kappa=0.095) (Figure 2). The IgG OD 229 ratio of convalescent sera was neither correlated with the CT-value of the diagnostic 230 swab $(p=0.666)$ (Supplemental Figure 2) nor with that of the convalescent swab $231(p=0.727)$.

232

233 The results of the multiple linear regression model on 200 patients with IgG results 234 and information from the survey showed that higher IgG antibody titers were 235 associated with age 45 to 60 years $(0.8,95 \% \mathrm{Cl} 0.05-1.6, \mathrm{p}=0.036)$, compared to age 23630 to 44$)$ and moderate/severe activity restriction $(2.1,95 \% \mathrm{Cl} 1.2-3.0, \mathrm{p}<0.001)$, 
medRxiv preprint doi: https://doi.org/10.1101/2021.03.15.21253267; this version posted March 17, 2021. The copyright holder for this preprint (which was not certified by peer review) is the author/funder, who has granted medRxiv a license to display the preprint in perpetuity.

It is made available under a CC-BY-NC-ND 4.0 International license .

237 compared to normal activity) (Table 2). A similar analysis carried out on the 120

238 participants with survey results and nAb titers showed that male gender $(2.2,95 \% \mathrm{Cl}$

239 0.9-5.6, $\mathrm{p}=0.097$, compared to female) and a CT-value of $25-30(4.9,95 \% \mathrm{Cl} 0.9$ -

240 25.8, $p=0.062$, compared to CT-value $>30$ ) from the diagnostic swab were associated

241 with high nAb titers in the univariate logistic regression model at the 0.1 level (Table

2423 and Supplemental Figure 3).

244 For the 63 participants tested with the nucleocapsid protein ELISA, IgG levels were

245 classified as negative for 24 (38.1\%), 11 (17.5\%) as weak positive, and 28 (44.4\%)

246 as high positive. The correlation between the spike protein and nucleocapsid protein

247 assays was 73.0\% (Kappa=0.548) and the nucleocapsid assay and nAbs was 16.7\%

248 (Kappa=0.022) (Supplemental Figure 4).

249

250 The illness severity score was analyzed separately as it combined multiple variables

251 that were already included in the regression models. Based on the categories

252 outlined above, 32.3\% (52/161) were defined as mild, 54.0\% (87/161) as moderate,

253 and $13.7 \%(22 / 161)$ as severe illness. Participants with severe disease had median

$254 \lg$ titers of 6.0 (IQR 3.8 to 7.6 ), compared to 2.5 (IQR 1.4 to 4.1 ) for those with mild

255 disease and 2.9 (IQR 1.5 to 4.7$)$ for moderate disease $(p<0.001)$. For nAbs, we

256 observed a trend that participants with more severe disease had high titers, but the

257 difference was not statistically significant (OR 1.9, 95\% Cl 0.9-3.8, $\mathrm{p}=0.084$ ). 
medRxiv preprint doi: https://doi.org/10.1101/2021.03.15.21253267; this version posted March 17, 2021. The copyright holder for this preprint (which was not certified by peer review) is the author/funder, who has granted medRxiv a license to display the preprint in perpetuity.

It is made available under a CC-BY-NC-ND 4.0 International license .

259 The 35 participants eligible for the follow-up testing had the second blood collection a

260 median of 46 days (IQR 23 to 57) after the convalescent testing. The median IgG OD

261 ratio was 3.7 (IQR 2.9 to 5.9$)$, and $74.3 \%$ (26/35) were categorized as having a high

262 positive IgG response. The IgG titers showed a median increase of 0.5 (IQR -0.3 to

263 1.7) from convalescent to follow-up testing $(p<0.001)$ (Table 1 and Figure 3$)$. The

264 nAbs titers from the six follow-up participants were all $\leq 1: 80$ (Figure 4).

\section{Discussion}

267 This study describes the antibody response in a cohort of 281 recovered COVID-19

268 patients. Our results show that older age (45-65 years) and more severe disease were associated with a stronger IgG response. This response was sustained up to 47 days after the convalescent sample in those who had a follow-up visit. However,

271 there was poor correlation between clinical characteristics and the strength of a 272 neutralizing antibody response. Furthermore, in the few participants that had nAbs

273 follow-up testing, a reduction in the neutralization capacity of the circulating IgG 274 antibodies was observed. The persistence of nAbs over time must be confirmed in 275 future studies with larger cohorts.

277 We found $15.3 \%$ of patients not to have an antibody response at initial testing. This 278 finding is similar to a finding in a study of over 1,300 SARS-CoV-2 patients in New 279 York City that reported IgG seroconversion to the S protein in $89 \%$ PCR-positive 280 patients at the time of initial testing from Wajnberg et al. Our observation of the IgG response being correlated with age and disease severity confirms the findings of a 
medRxiv preprint doi: https://doi.org/10.1101/2021.03.15.21253267; this version posted March 17, 2021. The copyright holder for this preprint (which was not certified by peer review) is the author/funder, who has granted medRxiv a license to display the preprint in perpetuity.

It is made available under a CC-BY-NC-ND 4.0 International license .

282 prior study by Klein et al, where older age and hospitalization was associated with

283 stronger anti-SARS-CoV-2 antibody response quantified by both IgG levels against

284 the S protein and nAb titers [10]. In this study of 126 plasma donors, male sex and

285 older age were also observed to be associated, however we were only able to

286 deduce an association of nAbs but not IgG levels with male sex.

While our study showed persistence of an $\lg G$ response after a month and a half in those with high initial IgG titers, a study of 365,000 adults in England by Ward et al. showed a decline in the prevalence of SARS-CoV-2 antibodies over the course of

291 three months. The decline in IgG positivity was greatest among those who reported 292 no symptoms, a population that was underrepresented in our study [16].

294 These findings have implications for the selection of convalescent donors of plasma 295 for plasma therapy [13]. Thus, in order to improve the anti-SARS-CoV-2 IgG titers 296 present in the donated plasma, donors should be selected from those with a more 297 severe course of COVID-19 disease and asked to donate plasma as soon as 298 possible after convalescence $[10,17]$. Furthermore, these findings might have 299 implications for immunity against repeat infections. However, further data is needed

300 to understand whether antibodies or T cells confer protective immunity to SARS301 CoV-2. 
medRxiv preprint doi: https://doi.org/10.1101/2021.03.15.21253267; this version posted March 17, 2021. The copyright holder for this preprint (which was not certified by peer review) is the author/funder, who has granted medRxiv a license to display the preprint in perpetuity.

It is made available under a CC-BY-NC-ND 4.0 International license .

303 At the convalescent study visit, $9 \%$ of participants remained positive for SARS-CoV-2

304 on PCR. However, all CT-values were $>30$, indicating a low viral load and likely non-

305 viable virus particles. These data are in line with other studies reporting positive PCR

306 results up to 28 days and longer after symptom resolution [3, 18-20]. Surprisingly,

307 persistent viral shedding was not associated with $\lg \mathrm{G}$ or $\mathrm{nAbs}$ response in our

308 analysis, supporting the idea that shed RNA is not an indicator of ongoing infection

$309[3,8]$.

310

311 This study has several limitations. The criteria for plasma donation restricted

312 participation to healthy people under 60 years of age. Further, the survey responses

313 showed that most participants had relatively mild COVID-19 disease, although

314 asymptomatic participants were underrepresented and very few were hospitalized.

315 These factors indicate that the results may not be generalizable to populations who

316 are older than 60 , have severe disease, have comorbidities, or to asymptomatic

317 patients. Most participants only had one serum sample collected, so there is limited

318 data on the change in antibody titers over time. The variability in the nAb response

319 would require evaluation of larger numbers of convalescent patients in order to yield

320 a better understanding of predictive factors.

321

322 This study also has several strengths. We present the IgG response in over 200

323 participants and nAbs in 145 participants. We also collected follow-up data for those

324 participants who had a strong $\lg G$ and $n A b s$ response at baseline. The information 
medRxiv preprint doi: https://doi.org/10.1101/2021.03.15.21253267; this version posted March 17, 2021. The copyright holder for this preprint (which was not certified by peer review) is the author/funder, who has granted medRxiv a license to display the preprint in perpetuity. It is made available under a CC-BY-NC-ND 4.0 International license.

325 on illness severity and PCR results from both diagnosis and convalescent time-points 326 provided a fuller clinical picture.

327

\section{Conclusion}

329 While older age and disease severity were correlated with stronger IgG responses,

330 the predictive factors for strong neutralizing antibody response in convalescent 331 patients remain unclear. 
medRxiv preprint doi: https://doi.org/10.1101/2021.03.15.21253267; this version posted March 17, 2021. The copyright holder for this preprint (which was not certified by peer review) is the author/funder, who has granted medRxiv a license to display the preprint in perpetuity.

It is made available under a CC-BY-NC-ND 4.0 International license .

\section{Footnote page:}

333 Conflict of interest: The authors declare that they have no competing interests.

334 Funding: This work was supported by the German Federal Ministry of Education and

335 Research (BMBF) program on emergency research funding for COVID-19 (funding

336 number 01KG20152) and internal funds of Heidelberg University Hospital.

\section{Corresponding author:}

338 Claudia M. Denkinger

339 Address: Section of Clinical Tropical Medicine, Center for Infectious Disease,

340 Heidelberg University Hospital, Im Neuenheimer Feld 324, Heidelberg 69120,

341 Germany

342 Telephone: 00496221 56-22999; Fax: 00496221 56-5204

343 Claudia.Denkinger@uni-heidelberg.de

344 Author contributions: CMD was responsible for the conceptualization and design of

345 the study and supervised the analysis and writing. MG was responsible for the 346 statistical analysis and writing. CMT, PK and TB were responsible for the literature

347 review and supported the conceptualization and design of the study. PK, YH, LR, JS,

348 MJ, NB, and TS were responsible for the survey and patient recruitment. SW and MJ

349 were responsible for the study visits and blood collection. HGK, RB, MSC, BM and

350 AP were responsible for the antibody testing. All authors contributed to data

351 interpretation, critically reviewed the first draft, and approved the final version and

352 agreed to be accountable for the work.

353 Ethical Approval: All procedures performed in studies involving human participants

354 were in accordance with the ethical standards of the institutional research committee 
medRxiv preprint doi: https://doi.org/10.1101/2021.03.15.21253267; this version posted March 17, 2021. The copyright holder for this preprint (which was not certified by peer review) is the author/funder, who has granted medRxiv a license to display the preprint in perpetuity. It is made available under a CC-BY-NC-ND 4.0 International license.

355 of Heidelberg University (S686/2018) and with the 1964 Helsinki declaration and its 356 later amendments or comparable ethical standards.

357 Acknowledgements: We would like to thank all the participants who contributed to 358 the survey and plasma donation study. We are grateful to Maria Anders-Össwein, 359 Stefanie Wolf, and Ira Pistorius for their dedicated expert technical assistance. 
medRxiv preprint doi: https://doi.org/10.1101/2021.03.15.21253267; this version posted March 17, 2021. The copyright holder for this preprint (which was not certified by peer review) is the author/funder, who has granted medRxiv a license to display the preprint in perpetuity.

It is made available under a CC-BY-NC-ND 4.0 International license .

360

361

362

363

364

365

366

367

368

369

370

371

372

373

374

375

376

377

378

382

379 8. Long Q-X, Tang X-J, Shi Q-L, et al. Clinical and immunological assessment of 380 asymptomatic SARS-CoV-2 infections. Nature Medicine 2020; 26:1200-4.

381 9. Bao L, Deng W, Gao H, et al. Reinfection could not occur in SARS-CoV-2 infected

\section{References}

1. Xiang F, Wang $\mathrm{X}$, He X, et al. Antibody Detection and Dynamic Characteristics in Patients With Coronavirus Disease 2019. Clinical infectious diseases : an official publication of the Infectious Diseases Society of America 2020; 71:1930-4.
2. Imai K, Kitagawa Y, Tabata S, et al. Antibody response patterns in COVID-19 patients with different levels of disease severity-Japan. medRxiv 2020:2020.11.20.20231696.

3. Tan W, Lu Y, Zhang J, et al. Viral Kinetics and Antibody Responses in Patients with COVID-19. medRxiv 2020:2020.03.24.20042382.

4. To KK-W, Tsang OT-Y, Leung W-S, et al. Temporal profiles of viral load in posterior oropharyngeal saliva samples and serum antibody responses during infection by SARS-CoV-2: an observational cohort study. The Lancet Infectious Diseases 2020; 20:565-74.

5. Zhao J, Yuan Q, Wang H, et al. Antibody responses to SARS-CoV-2 in patients of novel coronavirus disease 2019. Clinical Infectious Diseases 2020.

6. Chen Y, Zuiani A, Fischinger S, et al. Quick COVID-19 Healers Sustain AntiSARS-CoV-2 Antibody Production. Cell 2020; 183:1496-507.e16.

7. Iyer AS, Jones FK, Nodoushani A, et al. Dynamics and significance of the antibody response to SARS-CoV-2 infection. medRxiv 2020:2020.07.18.20155374. rhesus macaques. bioRxiv 2020:2020.03.13.990226. 
medRxiv preprint doi: https://doi.org/10.1101/2021.03.15.21253267; this version posted March 17, 2021. The copyright holder for this preprint (which was not certified by peer review) is the author/funder, who has granted medRxiv a license to display the preprint in perpetuity.

It is made available under a CC-BY-NC-ND 4.0 International license .

383 10. Klein SL, Pekosz A, Park H-S, et al. Sex, age, and hospitalization drive antibody

384 responses in a COVID-19 convalescent plasma donor population. medRxiv 2020:2020.06.26.20139063.

386 11. Ju B, Zhang Q, Ge X, et al. Potent human neutralizing antibodies elicited by

387 SARS-CoV-2 infection. bioRxiv 2020:2020.03.21.990770.

388 12. Valk SJ, Piechotta V, Chai KL, et al. Convalescent plasma or hyperimmune 389 immunoglobulin for people with COVID-19: a rapid review. The Cochrane database 390 of systematic reviews 2020; 5:Cd013600.

391 13. Administration UFaD. Recommendations for Investigational COVID-19 392 Convalescent Plasma. Available at: https://www.fda.gov/vaccines-blood-

393 biologics/investigational-new-drug-ind-or-device-exemption-ide-process-

394 cber/recommendations-investigational-covid-19-convalescent-plasma. 2021.

395 14. Simonovich VA, Burgos Pratx LD, Scibona P, et al. A Randomized Trial of 396 Convalescent Plasma in Covid-19 Severe Pneumonia. New England Journal of 397 Medicine 2020; 384:619-29.

398 15. Libster R, Pérez Marc G, Wappner D, et al. Early High-Titer Plasma Therapy to 399 Prevent Severe Covid-19 in Older Adults. New England Journal of Medicine 2021; $400 \quad 384: 610-8$.

401 16. Ward H, Cooke G, Atchison C, et al. Declining prevalence of antibody positivity to 402 SARS-CoV-2: a community study of 365,000 adults. medRxiv $403 \quad 2020: 2020.10 .26 .20219725$.

404 17. Wu F, Wang A, Liu M, et al. Neutralizing antibody responses to SARS-CoV-2 in a 405 COVID-19 recovered patient cohort and their implications. medRxiv $406 \quad 2020: 2020.03 .30 .20047365$. 
medRxiv preprint doi: https://doi.org/10.1101/2021.03.15.21253267; this version posted March 17, 2021. The copyright holder for this preprint (which was not certified by peer review) is the author/funder, who has granted medRxiv a license to display the preprint in perpetuity. It is made available under a CC-BY-NC-ND 4.0 International license.

407 18. Wajnberg A, Mansour M, Leven $E$, et al. Humoral immune response and 408 prolonged PCR positivity in a cohort of 1343 SARS-CoV 2 patients in the New York 409 City region. medRxiv 2020:2020.04.30.20085613.

410 19. Wang B, Wang L, Kong $X$, et al. Long-term coexistence of SARS-CoV-2 with 411 antibody response in COVID-19 patients. Journal of Medical Virology 2020; 92:16844129

413 20. Zhang G, Nie S, Zhang Z, Zhang Z. Longitudinal Change of Severe Acute 414 Respiratory Syndrome Coronavirus 2 Antibodies in Patients with Coronavirus 415 Disease 2019. The Journal of infectious diseases 2020; 222:183-8. 
medRxiv preprint doi: https://doi.org/10.1101/2021.03.15.21253267; this version posted March 17, 2021. The copyright holder for this preprint (which was not certified by peer review) is the author/funder, who has granted medRxiv a license to display the preprint in perpetuity.

It is made available under a CC-BY-NC-ND 4.0 International license.

417 Table 1. Demographic and clinical characteristic of participants with 418 convalescent testing $(\mathbf{n}=\mathbf{2 8 1})$

\begin{tabular}{|c|c|c|}
\hline & $n / N$ & $\%$ \\
\hline \multicolumn{3}{|c|}{ Demographics } \\
\hline Age, median [IQR] & 39 [29-50] & \\
\hline \multicolumn{3}{|l|}{ Gender } \\
\hline Male & 107/194 & 55.2 \\
\hline Female & $86 / 194$ & 44.3 \\
\hline Diverse & $1 / 194$ & 0.5 \\
\hline \multicolumn{3}{|l|}{ Diagnosis } \\
\hline $\begin{array}{l}\text { CT value of diagnostic swab, } \\
\text { median [IQR] }\end{array}$ & 25 [20-28] & \\
\hline \multicolumn{3}{|l|}{ CT value of diagnostic swab } \\
\hline$<25$ & & \\
\hline $25-30$ & $54 / 165$ & 32.7 \\
\hline$>30$ & $24 / 165$ & 14.6 \\
\hline \multicolumn{3}{|c|}{ Convalescent testing } \\
\hline $\begin{array}{l}\text { Days from diagnosis to } \\
\text { convalescent testing, median [IQR] }\end{array}$ & 34 [28-43] & \\
\hline Days from end of symptoms to & & \\
\hline
\end{tabular}


medRxiv preprint doi: https://doi.org/10.1101/2021.03.15.21253267; this version posted March 17, 2021. The copyright holder for this preprint (which was not certified by peer review) is the author/funder, who has granted medRxiv a license to display the preprint in perpetuity. It is made available under a CC-BY-NC-ND 4.0 International license .

\begin{tabular}{|c|c|c|}
\hline convalescent testing, median [IQR] & 29 [22-37] & \\
\hline \multicolumn{3}{|l|}{ Result of convalescent swab } \\
\hline Negative & $249 / 274$ & 90.9 \\
\hline Positive & $25 / 274$ & 9.1 \\
\hline $\begin{array}{l}\text { CT value of convalescent swab if } \\
\text { positive, median [IQR] }\end{array}$ & 37 [35-38] & \\
\hline IgG OD ratio, median [IQR] & $3.1[1.6-5.1]$ & \\
\hline \multicolumn{3}{|l|}{ IgG result } \\
\hline Negative/Borderline $(<1.1)$ & $43 / 281$ & 15.3 \\
\hline Weak positive (1.1-2.5) & $73 / 281$ & 26.0 \\
\hline High positive (>2.5) & $165 / 281$ & 58.7 \\
\hline \multicolumn{3}{|l|}{ Neutralizing Antibodies } \\
\hline Low $(\leq 1: 80)$ & $110 / 145$ & 75.9 \\
\hline High $(>1: 80)$ & $35 / 145$ & 24.1 \\
\hline \multicolumn{3}{|l|}{$\begin{array}{l}\text { Neutralizing Antibodies if } \\
\text { convalescent swab positive }\end{array}$} \\
\hline Low $(\leq 1: 80)$ & $15 / 20$ & 75.0 \\
\hline High $(>1: 80)$ & $5 / 20$ & 25.0 \\
\hline Follow-up testing & $(\mathrm{N}=35)$ & \\
\hline
\end{tabular}


medRxiv preprint doi: https://doi.org/10.1101/2021.03.15.21253267; this version posted March 17, 2021. The copyright holder for this preprint (which was not certified by peer review) is the author/funder, who has granted medRxiv a license to display the preprint in perpetuity.

It is made available under a CC-BY-NC-ND 4.0 International license .

\begin{tabular}{|c|c|c|c|}
\hline $\begin{array}{l}\text { Days from convalescent to follow- } \\
\text { up blood draw, median [IQR] }\end{array}$ & $46[23-57]$ & & \\
\hline Follow-up IgG result, median [IQR] & $3.7[2.9-5.9]$ & & \\
\hline Follow-up IgG result & & & \\
\hline Negative/Borderline $(<1.1)$ & $2 / 35$ & 5.7 & \\
\hline Weak positive (1.1-2.5) & $5 / 35$ & 14.3 & \\
\hline High positive (>2.5) & $28 / 35$ & 80.0 & \\
\hline $\begin{array}{l}\text { Change in IgG from convalescent } \\
\text { to follow-up, median [IQR] }\end{array}$ & $0.5[-0.3-1.7]$ & & \\
\hline $\begin{array}{l}\text { Follow-up Neutralizing Antibodies } \\
\text { Low }(\leq 1: 80)\end{array}$ & $6 / 6$ & 100.0 & \\
\hline $\begin{array}{l}{ }^{a} \text { Missing data: gender }=87, \text { CT value of } \\
\text { nAbs for convalescent swab-positive }=5\end{array}$ & agnostic swab= & 16 , resu & f convalescent swab $=7$, results of \\
\hline
\end{tabular}

423

424

425

Table 2. Description of factors associated with Convalescent SARS CoV-2 IgG

426

titers $(n=200)$

\begin{tabular}{|l|l|l|l|l|}
\hline Characteristic & Total & OD Ratio, & Simple Linear & Multiple Linear \\
$\mathrm{n} / \mathrm{N}(\%)$ & population & Median & Regression & Regression \\
& & {$[\mathrm{IQR}]$} & Coef $(95 \% \mathrm{Cl}), \mathrm{p}-$ & Coef $(95 \% \mathrm{Cl}), \mathrm{p}-$ \\
& & & & \\
\hline
\end{tabular}




\begin{tabular}{|c|c|c|c|c|}
\hline & & & value & value \\
\hline \multicolumn{5}{|c|}{ Demographic } \\
\hline \multicolumn{5}{|l|}{ Age } \\
\hline $18-29$ & $50 / 200(25.0)$ & $3.7[1.9-4.4]$ & $0.1(-0.8 ; 1.0), 0.829$ & $0.2(-0.7 ; 1.0), 0.666$ \\
\hline $30-44$ & 75/200 (37.5) & $2.6[1.2-4.5]$ & Reference & Reference \\
\hline $45-60$ & 75/200 (37.5) & $3.6[1.8-6.3]$ & $0.9(0.2 ; 1.7), 0.017$ & $0.8(0.05-1.6), 0.036$ \\
\hline \multicolumn{5}{|l|}{ Gender $^{a}$} \\
\hline Male & 107/194 (55.2) & $3.1[1.5-5.1]$ & $0.4(-0.4 ; 1.0), 0.405$ & \\
\hline Female & 86/194 (44.3) & $3.3[1.8-4.9]$ & Reference & \\
\hline Diverse $^{b}$ & 1/194 (0.5) & $8.4[8.4-8.4]$ & & \\
\hline \multicolumn{5}{|c|}{ Clinical } \\
\hline \multicolumn{5}{|l|}{ Activity Restriction } \\
\hline Normal activity & $51 / 188(27.1)$ & $2.2[1.2-3.9]$ & Reference & Reference \\
\hline Minimal restriction & $81 / 188(43.1)$ & 3.0 [1.8-4.3] & $0.5(-0.3 ; 1.4), 0.187$ & $0.6(-0.2 ; 1.4), 0.163$ \\
\hline Moderate/Severe & $56 / 188(29.8)$ & 5.0 [2.6-7.2] & $2.2(1.3 ; 3.1),<0.001$ & $2.1(1.2 ; 3.0),<0.001$ \\
\hline \multicolumn{5}{|l|}{ Symptomatic } \\
\hline No & 4/188 (2.1) & $2.5[0.9-4.0]$ & Reference & \\
\hline Yes & 184/188 (97.9) & $3.2[1.8-5.1]$ & $1.2(-1.2 ; 3.7), 0.325$ & \\
\hline Fever only & & & & \\
\hline
\end{tabular}




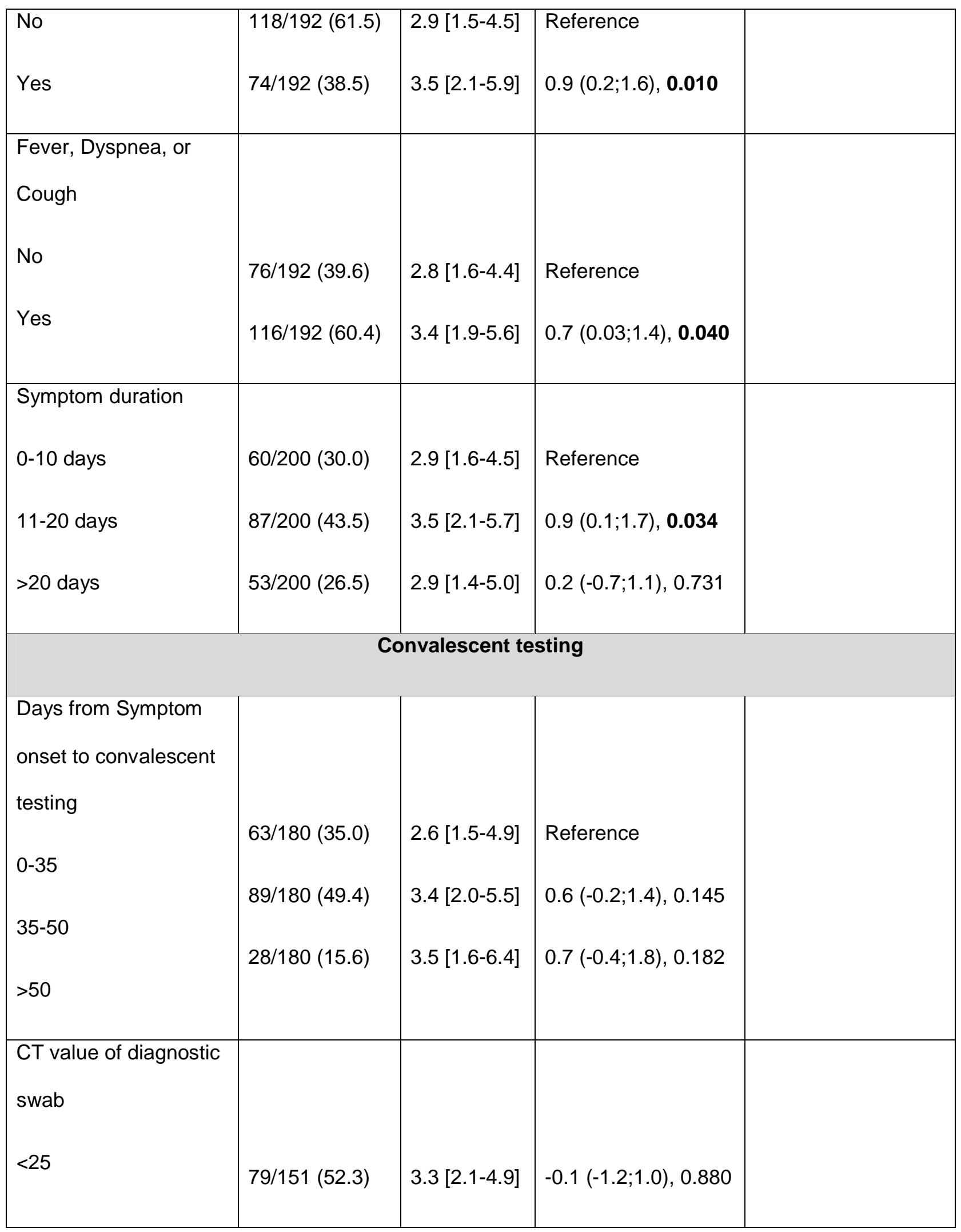


medRxiv preprint doi: https://doi.org/10.1101/2021.03.15.21253267; this version posted March 17, 2021. The copyright holder for this preprint (which was not certified by peer review) is the author/funder, who has granted medRxiv a license to display the preprint in perpetuity.

It is made available under a CC-BY-NC-ND 4.0 International license .

\begin{tabular}{|l|l|l|l|l|}
\hline $25-30$ & $48 / 151(31.8)$ & $3.6[1.6-5.8]$ & $0.3(-0.9 ; 1.6), 0.569$ & \\
\hline$>30$ & $24 / 151(15.9)$ & $3.5[1.9-4.8]$ & Reference & \\
\hline Result of convalescent & & & & \\
swab & $177 / 199(88.5)$ & $3.0[1.6-5.1]$ & Reference & \\
Pogative & $22 / 199(11.1)$ & $3.8[2.2-4.7]$ & $0.2(-0.9 ; 1.2), 0.780$ & \\
\hline
\end{tabular}

428 symptoms $n=20$; diagnostic swab $n=49$; convalescent swab $n=1$

$429 \quad{ }^{b}$ Diverse gender $(n=1)$ excluded from regression model

430

431

432 Table 3. Description of factors associated with Convalescent SARS CoV-2

433 Neutralizing antibody titers $(n=120)$

\begin{tabular}{|c|c|c|c|c|}
\hline $\begin{array}{l}\text { Characteristic } \\
\mathrm{n} / \mathrm{N}(\%)\end{array}$ & $\begin{array}{l}\text { Total } \\
\text { population }\end{array}$ & Low $(\leq 1: 80)$ & High $(>1: 80)$ & $\begin{array}{l}\text { Logistic Regression, } \\
\text { Univariate } \\
\text { OR }(95 \% \mathrm{Cl}), \mathrm{p}- \\
\text { value }\end{array}$ \\
\hline \multicolumn{5}{|c|}{ Demographic } \\
\hline \multicolumn{5}{|l|}{ Age } \\
\hline $18-29$ & $31 / 120(25.8)$ & $25 / 90(27.8)$ & 6/30 (20.0) & Reference \\
\hline $30-44$ & 40/120 (33.3) & $31 / 90(34.4)$ & 9/30 (30.0) & $1.2(0.4-3.9), 0.748$ \\
\hline
\end{tabular}


medRxiv preprint doi: https://doi.org/10.1101/2021.03.15.21253267; this version posted March 17, 2021. The copyright holder for this preprint (which was not certified by peer review) is the author/funder, who has granted medRxiv a license to display the preprint in perpetuity.

It is made available under a CC-BY-NC-ND 4.0 International license .

\begin{tabular}{|c|c|c|c|c|}
\hline $45-60$ & 49/120 (40.8) & $34 / 90(37.8)$ & $15 / 30(50.0)$ & $1.8(0.6-5.4), 0.269$ \\
\hline \multicolumn{5}{|l|}{ Gender $^{\mathrm{a}}$} \\
\hline Male & $63 / 116(54.3)$ & $45 / 89(50.6)$ & $18 / 27(66.7)$ & $2.2(0.9-5.6), 0.097$ \\
\hline Female & $52 / 116(44.8)$ & $44 / 89(49.4)$ & $8 / 27(29.6)$ & Reference \\
\hline Diverse $^{b}$ & $1 / 116(0.9)$ & 0 & $1 / 27(3.7)$ & \\
\hline \multicolumn{5}{|c|}{ Clinical } \\
\hline \multicolumn{5}{|l|}{ Activity Restriction } \\
\hline Normal activity & 27/114 (23.7) & $23 / 87(26.4)$ & $4 / 27(14.8)$ & Reference \\
\hline Minimal restriction & 43/114 (37.7) & $33 / 87(37.9)$ & $10 / 27(37.0)$ & $1.7(0.5-6.2), 0.394$ \\
\hline Moderate/Severe & $44 / 114(38.6)$ & $31 / 87(35.6)$ & $13 / 27(48.2)$ & $2.4(0.7-8.4), 0.165$ \\
\hline \multicolumn{5}{|l|}{ Fever only } \\
\hline No & $66 / 116(56.9)$ & $53 / 89(59.6)$ & $13 / 27(48.2)$ & Reference \\
\hline Yes & $50 / 116(43.1)$ & $36 / 89(40.5)$ & $14 / 27(51.9)$ & $1.6(0.7-3.8), 0.297$ \\
\hline \multicolumn{5}{|c|}{ Fever, Dyspnea, or Cough } \\
\hline No & $41 / 116(35.3)$ & $35 / 89$ (39.3) & 6/27 (22.2) & Reference \\
\hline Yes & $75 / 116(64.7)$ & $54 / 89(60.7)$ & $21 / 27(77.8)$ & $2.3(0.8-6.2), 0.109$ \\
\hline \multicolumn{5}{|l|}{ Symptom duration } \\
\hline $0-10$ days & $37 / 120(30.8)$ & $30 / 30(33.3)$ & 7/30 (23.3) & Reference \\
\hline $11-20$ days & $59 / 120(49.2)$ & $43 / 90(47.8)$ & $16 / 30(53.3)$ & $1.6(0.6-4.3), 0.362$ \\
\hline
\end{tabular}


medRxiv preprint doi: https://doi.org/10.1101/2021.03.15.21253267; this version posted March 17, 2021. The copyright holder for this preprint (which was not certified by peer review) is the author/funder, who has granted medRxiv a license to display the preprint in perpetuity.

It is made available under a CC-BY-NC-ND 4.0 International license .

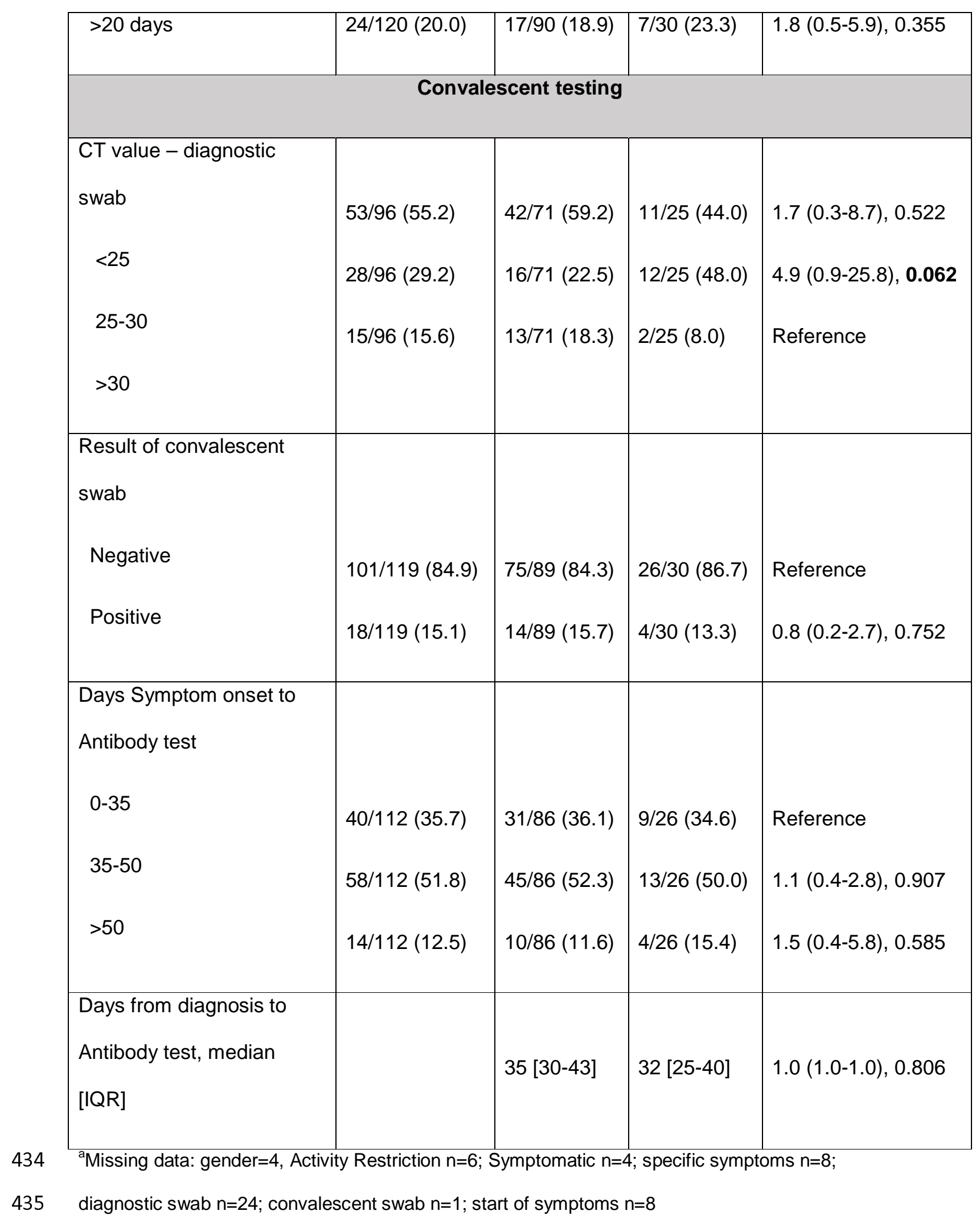


medRxiv preprint doi: https://doi.org/10.1101/2021.03.15.21253267; this version posted March 17, 2021. The copyright holder for this preprint (which was not certified by peer review) is the author/funder, who has granted medRxiv a license to display the preprint in perpetuity. It is made available under a CC-BY-NC-ND 4.0 International license .

436 biverse gender $(n=1)$ excluded from regression model

437

438 Figure titles and legends

439

440 Figure 1. Convalescent SARS CoV-2 IgG by age category

441 The IgG OD ratio at the convalescent visit by age of the participant.

442

443 Figure 2. Convalescent SARS CoV-2 Neutralizing antibody and IgG titers

444 The IgG OD ratio compared to the Neutralizing antibody titer at the convalescent visit.

445

446 Figure 3. Change in SARS CoV-2 IgG levels from Convalescent to Follow-up testing

447 The change in IgG OD ratio from the convalescent to the follow-up time points for 35 448 participants with available data. Dark blue lines indicate increasing OD ratio, and light blue 449 lines indicate the same or decreasing $O D$ ratio.

450

451 Figure 4. Change in SARS CoV-2 Neutralizing antibody from Convalescent to Follow452 up testing

453 The change in neutralizing antibody titers from the convalescent to the follow-up time points 454 for 5 participants with both timepoints available. There are two participants with 1:40 titers at 455 both Convalescent and Follow-up timepoints. 


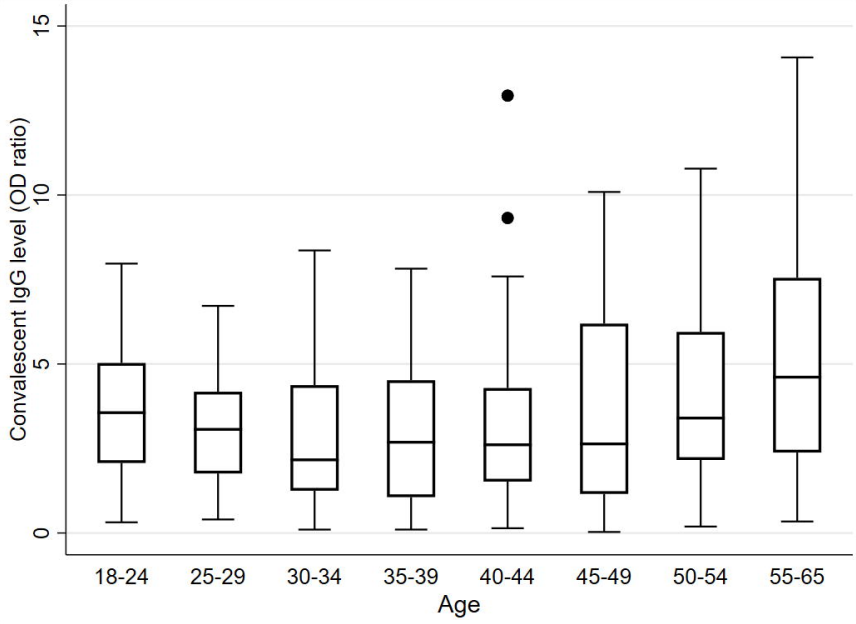




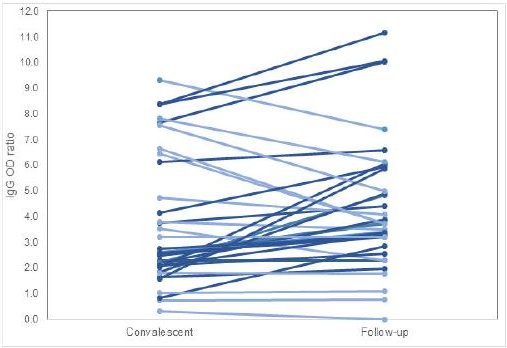


$1: 160$
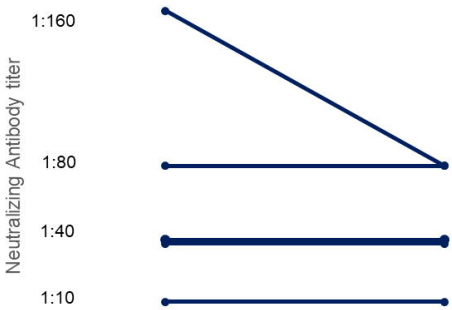

1:10

Follow-up 